\title{
Creating Bottom-up Development. A Study of Self-Organization and the Building of Fortune- Prosperity by the Torghuts from the Bulgan Sum in Mongolia
}

\author{
Tomasz Rakowski
}

DOI: 10.21104/CL.2016.1.07

\begin{abstract}
Local communities in nonWestern countries are often treated by international institutions as rather passive subjects, which need to be taught by experts and re-organized according to Western socioeconomic models (Hobart 1993). As a result of such an approach, many development agencies tend to overlook and omit the locals' own forms of social activity and their ideas of self-organization. In this article I would like to focus on the bottomup process of change in contemporary Mongolia and the Mongolians' own idiomatic ideas and practices of initiating and arranging development. I refer to research conducted in the Bulgan Sum (district), which is located on the southern slopes of the Altai. I have been conducting fieldwork among contemporary Torghuts since 2012. I mainly focus on the posttransitional economic activities in Bulgan, which involve collective management of goods (Empson 2014) and many new kinds of business related to cross-border trade. In the study I write about informal networks of businessmen and their way of fostering kinship relations in business. In this context I analyze the activity of the 'Torgon Nutag Club', established by a group of Torguud businessmen, who initiated and organized numerous social and cultural events and celebrations in their hometown. The majority of club members
\end{abstract}

live in Ulaanbaatar, in the so-called 'Torghut Town', which can now be considered one of the main intellectual centres where the Torghuts are active. What is particularly important here is that in this way the Torghuts create not only spontaneous and original social organizations, but also the idioms of spiritually-beneficial action, thus stimulating elements of a common fate, fortune-prosperity, life energy and potency.

Keywords development, self-organization, prosperity, buyan, Torghuts, Mongolia

This article was written as part of the Polish National Science Centre's project NN 109 180440, nr um. 1804/B/H03/2011/40.

Contact Tomasz Rakowski, Ph.D., Institute of Ethnology and Cultural Anthropology, University of Warsaw, Żurawia 4, 00-503, Warsaw, Poland; e-mail: tomaszrak@tlen.pl.

Jak citovat / How to cite Rakowski, Tomasz. (2016). Creating Bottom-up Development. A Study of Self-Organization and the Building of Fortune-Prosperity by the Torghuts from the Bulgan Sum in Mongolia. Český lid 103, 119-134. doi:http:// dx.doi.org/10.21104/CL.2016.1.07 
In this article I focus on the process of change and development in Western Mongolia, where local, bottom-up forms of development activities are so strong that they are practically the leading cause of change. I follow and examine changes taking place in the community of Bulgan, which is a town located on the southern slopes of the Altai, inhabited mostly by Torghuts. ${ }^{1}$ The inhabitants of Bulgan created an original model of development, on the one hand complying with local notions of modernization, and on the other, combining globalization, relocation and the contemporary mobility of social actors. The Bulgans now create their economic practices anew, act according to their own post-pastoral idioms and build their development ideas, deeply rooted in contemporary Mongolian spirituality, in local ways of gaining success and fortune-prosperity.

From an anthropological viewpoint, in various studies many socioeconomic programmes designed to initiate development in non-Western countries have presented a vision of the local organization of social life or local economy as a passive structure, requiring externally controlled change and resisting the processes of development and modernization (Crewe - Harris 2002: 43-46; Ferguson 1994; Mosse 2005). Such an attitude thus denies these societies their own modernization mechanisms (Hobart 1993: 3-12). Of particular importance here is the moment when the knowledge about the development and change created by local social actors is ignored. This is the case because experts are usually the ones who devise all the development programmes of large, worldwide international organizations, relying on the latest knowledge about the economy, agricultural engineering and technology, and they rarely take into account any practical, bottom-up knowledge of local societies about their own possibilities of modernization. Therefore, development programmes naturally have a rather schematic idea about how the societies function which they are trying to help, and, at the same time, on the basis of this model, they predict changes and the transition from point A to point B of development. Such an approach simultaneously assumes that expertise and knowledge about technology or organization should be transferred to local communities, to non-Western management systems, which should then result in the planned process of economic (and consequentially - social) development. Therefore, it is clearly a theological way of thinking, focused on the point of destination, which can be perfectly illustrated when it is compared with contrasting ideas of development, e.g. in Indonesia (Hobart 1993), a term for development, perkembangan, means spontaneous flourishing or growth (an organic metaphor related to the development of the inflorescence), which shows a different way of thinking, not necessarily in the categories of externally imposed goals and a new, externally stimulated process. As demonstrated

1 In a small percentage also by other Mongolian groups such as Hoshuuts, Dorbets, Uriankhai, Zakhchins, and also by a large group of Mongolian Kazakhs, reaching up to $30 \%$ of the local population. 
by Mark Hobart, the process of building development programmes and understanding development as such, a priori assumes an imbalance in the possession of knowledge and at the same time the image of its simple, undisturbed transfer from the actor possessing its more developed form to the one who still needs his knowledge to develop. In reality, however, it is crucial to point out here that the local bottom-up knowledge of these societies, which has until now allowed for all economic, technical and organizational activities, is usually almost completely ignored and rejected. Moreover, the imposition of expertise and organizational knowledge usually goes hand in hand with ignoring the knowledge already possessed, thus the knowledge brought from the outside is also ignored and rejected, but this time by its recipients - resistance, omission, and dissimulation appear.

If we take a closer look, it becomes apparent that the whole classical theory, which imposes the need to stimulate economic growth in non-Western countries, firstly assumes its orientation, the transition to the stage of the 'necessary development', 'take off', typically found in the writings of Walt Rostow (1960). Secondly, it assumes the transfer of development to the areas which lack developmental mechanisms, thus depriving members of local communities of their own skills, making their knowledge insufficient and unable to induce change and transformation. In this way members of the community, who are addressees of development projects, are from now on perceived as passive actors of changes, mere witnesses to something that comes from the outside. Importantly, this image of change coming from the outside is present both in the 'modernization theory', the vision of initiating or designing development in non-Western countries, as well as in the critical, deconstructing development ideas of “dependency theory”. In the latter, international programmes of development aid are presented as imposing locally very unfavourable economic conditions to the benefit of global capitalist enterprises, which profit from it (these profits are later on incorporated into global circulation). The rejection of local, practical knowledge and the whole repertoire of bottom-up economic activities also brings other consequences, which are often entirely unpredictable. In such situations different local tactics of resistance frequently combine with an only apparent fulfilment of the new requirements of development programmes (also the countries that are the recipients of these programmes and which need to fulfil these requirements).

This also reveals the manner in which local communities try to preserve their own way of making their living, which is combined with a quiet, effective resistance. The development process described by James Ferguson (1994) in South Africa's Lesotho can serve as a good example here. A World Bank project assumed that the majority of people living outside the capital made their living off cattle, thus to make cattle farming more effective they instructed herders to fence off their land with high fences and replace their herds with new ones (to purchase new, young, much more expensive herds, which 
would grow to provide higher meat production). Ferguson showed that the Bashoto people mostly supported their families by working abroad or in South African mines, while cattle were a sign of prestige and a form of unofficial retirement provision. Therefore, most herders found the idea of selling off large quantities of cattle on a commercial basis as inconceivable, as was fencing off the land (those who build fences are considered traitors to the community of herders, who integrate their pastures and lead common grazing). Moreover, some of the local politicians used the programme to strengthen their position, so political games also became apparent within the scope of the seemingly neutral programme of subsidizing pastoral farming (later it also became related to the formation of new centres of administrative authorities, already located near pastures and exercising even stronger supervision). Ferguson thus demonstrates that the picture of Lesotho society produced by the World Bank planners had overlooked some local 'real-life tactics', providing a continuous income in later life, and the whole sphere of local 'political life' and the perpetration of local political organizations. Thus the research conducted by Ferguson not only revealed a poorly functioning development mechanism, but also some unexpected bottom-up adaptations and various tactics applied by the recipients of the programme. It also unveiled the whole complex local mechanism of coping and building one's position, as well as the image of a local socio-political world associated with the ideas and actions for the organization of local life.

This kind of discourse, as produced by the planners and development agencies, has taken a similar form in Mongolia. During the post-socialist transformation, such organizations as the World Bank and the Asian Development Bank claimed that the traditional Mongolian cooperation in the use of land, pastures (Sneath 2002; 2003), many other goods and real estate needed to be changed first - that they had to be formalized and regulated. According to development expertise, granting, for example, land ownership will result in better care and management of both pastoral and urban areas. The lack of a system of private land ownership or in general was perceived as an obstacle or burden, hindering the processes of development and transformation (Sneath 2002; 2003)). Therefore, such an approach could again ignore and overlook something that creates local social life in a complex manner, something that is one of the centres of the bottom-up Mongolian mechanism of social functioning. Various researchers have demonstrated that it was this interference in the complex ways of the functioning of local communities, along with the development activities, that resulted in some kind of resistance and organized dissent, or even the opposite, negative effect of development activities (see Crewe - Harrison 2000). However, particularly important here are the works pointing to the shift in development activities towards these very local groups and understanding their own methods of development. There are researchers who recognize and try to indicate in their works the existence of 
alternative social mechanisms embedded in local structures and ways of development, such as the studies by Magdalena Villarreal (2007) on the female founders of cooperative apiaries in Mexico, or even the studies by Alberto Arce and Norman Long (2000) on the mechanisms of social self-organization related to the illicit cultivation of cocaine shrubs in Bolivia.

What I would like to take a close look at in this paper are the moments which reveal social action and the organization of development and change; however, this is not imposed so much from the outside through modernization programmes, rather it emerges spontaneously among the local social actors in Bulgan, Western Mongolia. Therefore, my research in the Bulgan Sum points to quite different conclusions concerning local development than those of the studies which focus mainly on the external ideas of modernization imposed on non-Western societies. What is more, the local energies of development emerge in the actions that 'exhilarate' social actors. They also fill their lives in a very reflexive, familiar manner, which however requires enormous ingenuity, effort, and expertise, bringing risk and competition. Though they do absorb external ideas and national conditions, they produce their own models of development and rebuild them appropriately; sometimes they occur in spite of the existing, external programmes (their mode of irrigating fields is still under local, customary regulation and remains independent from some suggestions made by international, environmental agencies), sometimes they benefit from their presence (the expansion of a hotel restaurant-club or organization of orchard and gardening fairs), yet the externally developed projects, though quite numerous, mostly finish after short periods of time, and bring quite insignificant effects for many of our interlocutors (such activities seemed often unclear, hiding the real cash flow). ${ }^{2}$ Still, what is particularly important here is that in this way Torghuts produce not only some spontaneous and original social organizations, but also produce idioms of 'spiritually beneficial' action, thus stimulating elements of a common fate, fortune-prosperity, life energy and potency. This article is based on the research carried out in the Bulgan Sum, which borders China's Xinjiang, between 2012 and 2015, at a time of numerous new investments, construction of roads, reconstruction of public places and the development of bottom-up Torghut organizations. I conducted my studies in a team with a Mongolian researcher, Oyungerel Tangad, and we cooperated with the Polish researchers Lech Mróz and Jerzy Wasilewski. We conducted interviews and observations, lived with Bulgan families, met on Skype and Facebook, and travelled the long distance between Bulgan and Ulaanbaatar on several occasions. In the last two years of the research we met

2 The majority of them are projects conducted by Merci Corps, USAid, and the governmental programmes coordinated by the authorities of the larger administrative unit, Hovd ajmag. Still, one positive example often cited by our respondents is the 12-year-long work by an Australian missionary, Jill Howe, who lived there until 2012 (the beginning of our research) and organized effective and well-remembered medical and social aid. 
and spoke to Torghut businessmen operating in Ulaanbaatar, who live in one of the Torghut housing estates - a complex of apartments, student dorms and also the location of numerous Torghut companies and enterprises.

\section{A new generation of Torghut businessmen: cooperative practices}

For decades Bulgan Sum (district) had been a place where, apart from herding, people were occupied with other activities, such as the cultivation of vegetables and fruit, and which developed in a slightly different direction from the rest of the country (Szynkiewicz 1977; Mróz 1977). Back in the 1960s the Sum underwent government-supported modernization, which included the creation of processing plants and cooperative workplaces. At the time of transformation and the collapse of the Mongolian People's State, which had been dependent on the Soviet Union, the life of Torghuts in Bulgan began to rapidly change. On the one hand, collective farms (negdel) and brigades collapsed, orchards and irrigated fields became neglected, the local power plant gradually became dilapidated and the lights went out, 'Bulgan gets dark', said the owners of a small local shop. On the other hand, small businessmen and traders came to Bulgan, trade on the border with China has intensified since the late 1990s, and Torghuts, especially the descendants of the Wangin (and also Howog-Sair) group, who had traditionally held important positions in the administration, also gradually begin to do business in Ulaanbaatar. The largest, most powerful businesses in the Mongolian capital, such as the 'Tavan Bogd' trade group, a network of supermarkets 'Nomin', the banking group 'Khan Bank', the famous 'State Department Store', and many smaller businesses and corporations, have been created by Torghut businessmen since the 1990s. Bulgan itself started to expand rapidly after hard years of transformation, and a new generation has taken over trade and business. These are the sons of herders and workers of negdels, usually Torghuts from the Beelin group, who after graduation start by trading at the border and also sourcing goods from Russia, then they open up hotels and karaoke clubs, shops, and after a few years they commute to their businesses in the capital. They built there a 5-storey block of flats, offices, shops and restaurants, which is now a gathering place for the Bulgans in the capital and is informally called 'Torghut Town'. This is where the Bulgans stop off at when they come to the capital. Here they organize goods to sell to China and the most resourceful entrepreneurs, such as 53-year-old Batnasan, organize events to celebrate the lunar New Year (Tsagaan Sar) for the Bulgans, or help to arrange and organize treatment for patients from Bulgan. At the same time they constantly travel between Bulgan and Ulaanbaatar in increasingly upmarket Toyota Land Cruisers, completing the route of more than 1,600 kilometres (half of it wilderness and dirt roads) in less than twenty hours. 
The Torghuts have achieved their business position in different ways. Many enterprises are commonly owned, based on kinship ties and on close relations within their group. Family members work together, they share their equipment and cars, and they mutually look after their premises. For example, one of them, 58-year-old Enkhbold, would look after his store in Torghut Town in the evenings, and when he was on a trip, his brother, who had just finished university, would regularly cover for him. Such close relations are to be found particularly in the Torghut Town block-estate. Torghut families are present everywhere in the neighbouring commercial premises, at the hairdressers, pawnshops, convenience stores and at the premises with pool tables. When I was there, my good friend 23-year-old Nomin, a Torghut, greeted everyone in a very familiar manner - he constantly explained that these are his aunts, uncles, cousins, brothers and sisters. They let their relatives from Bulgan young families, children, students who came to Ulaanbaatar to study - use their apartments. Offices and companies are located downstairs on two middle floors. The same groups of people work there - for example, the wife of one of the most dynamic businessmen works in a company run by Enkhbold, which is located right next door. On the ground floor, next to the Enkhbold's store, there is a restaurant run by his cousin, also a Torghut, who employs mostly members of both families. Similar relationships and interdependencies relate to the Torghuts' cars which are parked there. Expensive, giant cars are bought by several brothers and used as needed; they drive the whole family to Bulgan. When one of the brothers was collecting fuel money, he was wondering all the time what he would say to his older brother; and when another brother was driving us around the outskirts of the capital, then another younger brother appeared at a gas station and took over driving the car - it turned out that the older one did not have a license allowing him to drive in the city.

At the same time, the business run by the Torghuts is flourishing in Bulgan at the foot of the Altai. As with the former orchards, the land is intensely irrigated and local growers develop new varieties of plums and apples, watermelon and melon fields emerge, as well as sea buckthorn farms. However, they have mostly contributed to the rapid increase in cross-border trade and small trade in general, which attracts people from traditionally stock-breeding families. Fewer and fewer people are involved in animal farming, and since the herds were wiped out in the frost (zud) of 2009, almost all the young people have been looking for other work. The Torghuts have gradually built relations with trading partners in Xinjiang in China, where they cooperate with Kazakhs, local Torghuts, Uyghurs, and the Chinese; they have improved their command of foreign languages and the Torghut dialect itself, which is mainly to be found across the Chinese border, and some of them know Chinese. They mainly trade on the Yarant-Takshiken border marketplace and in shops and warehouses. However, many of my interlocutors, including 43-year-old Javzaa, who trades between Bulgan and Takshiken, claim that dozens of shops, hotels 
and karaoke clubs in Bulgan depend on the trade and small businesses from across the border. Bulgan inhabitants purchase their basic building and finishing materials, furniture and household goods at the market in Takshiken, taking advantage of community solidarity: it is common practice for those who go to Takshiken to collect orders for others. At the same time, through networks of informal contacts, Mongolian Torghuts sell goods bought in Ulaanbaatar in China: Russian pasta, Mongolian and Korean cosmetics, Russian sweets, and canned goods from Polish Urbanek.

I would like to draw attention here to the ongoing informal and mutual help, and the exchange of favours among members of the society, which also involves the complex self-organization and structures of pastoral / kin cooperation in modern Mongolia. Groups of relatives and communities of brothers and sisters run their businesses together, combining their funds, skills and networks of friends. In one example, the beginnings of cross-border trade meant gaining friends among Kazakhs, who helped move leather and meat across the border to China, and then pasta, candies, Mongolian carpets, felt products and other commodities; the shift manager in a local customs office was an uncle of a family from Bulgan which I had befriended, while their sister worked in the local bank branch in whose office I was allowed to check my emails. In this way, after many years of building relations and making friends on the border between Yarant and Takshiken, the movement of goods has become relatively fast and efficient. Here it is clear how a new sense of cooperation emerges between what is historical and refers to families cooperating in a collectivized cooperative economy (see Sneath 2003; Szynkiewicz 1981; Szynkiewicz 1993), and what is new and refers to the post-transformation reality, which witnessed 'the age of the market' (zah zeeliin uye, see Sneath 2002; Szynkiewicz 1993; see also Wheeler 2004). I find this manner of cooperation particularly interesting, i.e. the whole spectrum of behaviour and forms of organization, from informal, quiet activities based on kinship and family and ties of friendship (often adults from the same school closely cooperate with one another), through forms of self-organization and mutual support, organizing informal 'access' and 'deals', all the way to the discovery of very complex mechanisms governing this sphere. David Sneath (2003) and Sławoj Szynkiewicz (1981) demonstrated how the use of various goods is linked in Mongolia to a very complicated system of sharing pastures. In this way it is possible to look for new grazing land and at the same time it allows for the coexistence of many families and herding groups in the same areas, generating a surplus of meat, leather, and even dairy products. In Mongolia there exists a kind of 'temporary possession' of goods (Empson 2014), so the right to possess and use land is an axis of informal, customary division of labour, access to land and even to such things as cars, machines, shops or apartments. On the one hand, it creates an informal manner for using common property, but also allows for extortion, movement of the borders, taking over pasture land, 
but on the other hand, it is primarily related to its complicated use and the organization of herders as users of common/shared goods (animals, knowledge, pasture land), which can be even conceived as relating to Pfaffenberger's 'socio-technical system' (Sneath 2003: 446; see also Pfaffenberger 1992).

\section{Celebrations, ceremonies, events. Energies of development}

Such cooperation and informal collaboration in kinship groups represents something that is very local, Mongolian and idiomatic, but at the same time it may be perceived as a display of circumventing state regulations. However, ethnographic studies show that, in contrast to European traditions, the informality associated with kinship and friendship ties exists within the state and within the law, both in Mongolia (Tangad 2013) and in the post-Soviet area in general (Humphrey 2002). Tangad demonstrates that Mongolia, which has just started on the path to democracy, is now creating its own legal and state apparatus, but the law and state still encompass the whole informal, illegal way of doing things, such as settlements between feuding parties (the Mongolians claim that the courts are often less 'fair' than the local authorities, as the former involves bribes and 'accessing'). Mongolian legal regulations, therefore, often seem elusive, modifiable and can be circumvented. There is a saying that the law in Mongolia 'is valid up to three days', which means that regulations are constantly subject to dissolution, tampering, bypassing, e.g. they move land borders, students buy 'access' to academics (see also Humphrey 2012). Tangad shows that the state is thus filled with informal logic, its principles are - as is often said - 'Mongolized' (mongoltsloh), i.e. they gradually become susceptible to influence and interpersonal relations.

In Bulgan such a way of building cooperation and settling matters is also linked to the bottom-up activities of a group of brothers, Torhut's businessmen from Ulaanbaatar, for the benefit of the Sum. The activities of the new generation of businessmen have become partially incorporated into the structure and administration of the state and now complement and co-create them. In 2009 , some of those already living mostly in Ulaanbaatar (including the founders of the Torghut Town) decided to support, or even worship their place of birth and origin, and they started to work hard to develop it. This is related to Mongolian cosmology and images of the life force contained in the landscape and their place of origin in the nutag (Humphrey - Ujeed 2012: 160-161). ${ }^{3}$ In this case, worship of the place of origin takes the form of a self-organized club of activists. At some point they spontaneously convened an association they called the "Torgon Nutag Club" and the businessmen started to organize support for the Sum (though not fully effective), for example, during the severe

3 Which is why many Mongolians bring photos and objects from their homeland, paintings of the mountains, and many of them go on a pilgrimage there in the summer to visit their loved ones. 
winter disaster $(z u d)$ in 2009, when almost half of the entire livestock died. Most importantly they built and funded the 'park of glory', 'Torgon Nutag Park' (officially called 'Sorhogtani Khatny Neremjit Park') in the city centre, though slightly removed on the empty meadows by the river. There is a monument to Duke Ubashi Khan, who led the Torghuts from Kalmykia back to their homeland in the 18th century, which is decorated with Buddhist symbols, fountains, plaques with a list of the founders of the park, roofing, benches and even a basketball court. They also began to organize and fund the tachilga sacrificial ceremonies, which bring together the local community. They even organized the entire Naadam festival with horse races (including Torghut pacers), wrestling, concerts and ceremonies, during which awards are given to the best herders, businessmen, teachers, officials or just fathers and mothers. Although there are large annual celebrations in the Sum, such as anniversaries of a nursery or fruit-harvesting fair, the club also started to organize their own alternative or additional events. These are always extravagant - with concerts, speeches and sports competitions. The most important is the main ceremony worshiping the sacred mother-mountain of the Bulgans, Buuren Khayrkhan, which is held every two years. The club decided, however, that the ceremony of 'feeding' the mountain would not take place in the spring, which would be in line with the lama calendar, but in September, after haymaking and the movement of livestock to the autumn pastures, when all the businessmen can get from Ulaanbaatar to Bulgan. Then a column of decorated Toyota Land Cruisers, fully packed with businessmen and their families (mostly elderly, parents), arrives at the Sum. Beforehand the whole group goes by car across the whole of Mongolia, stopping off for a sip of vodka from ornate mini goblets, blessing and sprinkling the first drops of vodka. The locals and authorities of the Sum greet them at the town gate, offer them cups with milk, served on white sashes called hadag, fruit, tomatoes - the whole road is filled with people greeting one another.

The three-day festival, which is a continuous worship of the town, thus begins. Businessmen, their families and friends meet at horse races, they taste marmots and raise a toast. On one of the days, from early morning, groups of men tour one sacred mountain after another - they travel fast in a large group of Toyota Land Cruisers, then in groups of a few dozen men they climb various sacred peaks, where they toss rice and grain, sprinkle them with milk, vodka, and sometimes even with cognac. They also pray and recite the prayers along with a senior lama from the local temple. Later on they celebrate their holiday together (in a joint prayer under Buuren Khayrkhan, with hundreds of participants), as well as the opening of a new hall in the local 'House of Culture', hours of concerts, speeches and the presentations of awards for residents. Awards for horse racing and wrestling are funded by individual businessmen, who decorate the winners with medals and give them framed diplomas with the amount of prize money inscribed on them. On this particular 
occasion traders and businessmen played a public role, imitating or even mirroring local officials in their actions. In this way the boundaries between the activities of institutions and non-institutions have become blurred. In 2013 I asked whether the Sum was going to organize any large festivals that autumn and I was told, 'Probably yes, but if they delay it, then in the end people here [businessmen] will organize something themselves sooner... No-one will wait for ever, that's for sure'. The activities of local groups, artists and employees of Torghut companies and families from the town combine and intertwine with the activities of local officials, and all of this comes together as a feeling of doing something together. At the same time the money and time spent on the event are displayed on the council notice board. Moreover, the workflow and cash flow are very spontaneous. They come to an agreement about donations, decisions and details regarding the programme through informal conversations and meetings in local restaurants. In this way they build up their local position and establish relations that determine their success, while being very careful to make use of any informal access to officials, politicians and prosecutors. Such relations are based on a desire to make them quasi familylike and 'Mongolian', which does not necessarily mean favourable or friendly. Quite the opposite, they always bear a certain risk, understatement and in the case of favours - they never guarantee an 'obligatory return' on the invested work or the donations (see Humphrey 2012).

Any activities for the benefit of nutag - the place of birth and origin - are a wider phenomenon. In Mongolia 'local councils' (nutag-councils), which integrate the communities of the districts/Sums in Ulaanbaatar and lobby in parliament for the home towns and villages, have been functioning for years (Stolpe 2013: 15). Here we are dealing with a similar, though less formal, structure, which is created spontaneously outside the framework of the state, primarily involving the community of businessmen, the founders of small- and medium-sized companies. From a certain point of view, such a history of cooperation as the 'Torgon Nutag Club' may open up yet another path to yet another sense of acting for the benefit of the local community. Caroline Humphrey (2012: 26-28) writes that making any informal deals outside the state (though in this case also within the state) is ,more than merely a way of doing things, getting something, profiting from something or gaining some tangible benefits. Paradoxically, in this way the Mongolians understand a certain idea of cooperation and a certain art of being helpful and generous. In this way they create the art of making oneself 'somebody' in the eyes of others, and in this way being oneself can achieve a certain 'self-esteem'. Working on the border and developing businesses based on kinship and friendship, and constantly seeking contact with one's family, is not only a quiet and smart activity, but it is also the art of succeeding and gaining respect. This public display of 'doing great' and showing the superiority of one's actions is deeply rooted in the manner of thinking about organizational activities, about creating events to 
make people proud, such as celebrating Buuren Khayrkhan, or about building the 'park of glory'. All of these activities; bestowing awards or performances at ceremonies, represent a moment in time when not only do one's esteem and respectability grow, but it also opens up the possibility of success and intensifies the feeling of doing a 'good deed'. So it is not a quasi-economic transaction on the verge of nepotism, but rather a communitarian, non-individualistic achievement of a certain position in the eyes of others and oneself. David Sneath (2006) sees it more as the informal materialization of interpersonal relations, and the achievement not only of particular measurable benefits, but rather the achievement of a desired position in life. Instead of transacting (exchange and transfer of goods and services), Sneath (2006: 98) writes about enacting (the achievement / construction of a social role).

When one is acting for the benefit of one's home town (and one's nutag), friends, family, citizens, or doing all sorts of favours and making donations, it is not usually about returning the favour or gaining anything specific, but rather it is about the 'aesthetics' of this act ('moral aesthetic', see Humphrey 2012: 23; see also the discussion in Empson 2012: 11). In this way the art of informal action is not only the art of achieving goals, but also the art of building and strengthening the community. At this point there is a connection between informal cooperation and the cosmological dimension - creating the 'strength of success' through a complicated architecture of relations and providing 'life-force' (see Humphrey - Ujeed 2012; Tangad 2013: 105-121). If it involves intelligence, force and courage, then such a notion will be presented as a "wind horse" (hiimori) - a force moving upwards, radiating to others and alluring. Apart from the individual forces of a given person (sülde) and his presentation or realization (hiimori) through organizing his life and reciprocating, a certain social force also emerges, which gathers people around strong, clever, creative personalities. At this point it will probably be the element of life force called buyan, which stands for fortune-prosperity and is accumulated as a network of relations: friends, deeds and an abundance of potential favours. ${ }^{4}$

The accumulation of buyan is also related to the idea of achieving some kind of leadership, which can be demonstrated both through deeds and through the possession of goods ('when I want to collect from others $5 \mathrm{~m}$ tugriks each, then you have to put up 50m tugriks yourself. Then others follow me,' said one of the founders of the club). The organization of various events, which involves both people and hosts (ezene) from the surrounding mountains and rivers, makes the buyan or the organizers expand: 'people are grateful, they enjoy themselves and think well about him, they are happy about

4 This is the moment of building a positive turn of events by means of gathering the force/ power of relationships and exchanges with other people - as a Mongolian saying, quoted by Oyungerel Tangad goes: 'a person with many friends is like a huge steppe, and the one who does not have any friends is as small as the palm of your hand' (Tangad 2013: 221). 
the expansion of the buyan', a young female social worker from Bulgan told us. In this way it also reveals a certain specific path for achieving prosperity through others, through doing things with others, family and friends (for example, the constant celebration of relationships between male and female pupils from the same grade and school). This is the moment of a very intensive "taming" or "harnessing" of prosperity (fortune-prosperity), making it present in the family and among people (Empson 2012). Through the participation in and organization of celebrations and donations, not only are a person's force, position, buyan and even more personal hiimori or 'movement upwards' advertised, but also at the same time the spiral of possible and desired prosperity is set in motion.

\section{Summary: cooperation, prosperity, bottom-up idioms of development}

Within the international-development institutions in Mongolia, a modernization discourse has emerged (see Sneath 2003), which also - like in the case of Lesotho described by Ferguson - regards many forms of bottom-up activities and organizations as a hindrance to development. In Mongolia such a hindrance towards any developmental change comes in the form of group cooperation, based on kinship relations, which is often associated with nepotism and accusations concerning the informal provision of favours. David Sneath (2006) and Oyungerel Tangad (2013) show that at the moment of transition to democracy this use of contacts, gift endowment and exchange of favours in business and politics have simply become more visible. On the other hand, Sneath and Tangad show that forced relations based on 'connections' (also gifts-bribes and favours) to get access to crucial markets or transactions of high-importance, differ significantly from the ordinary arrangement of the transportation of yurts and household appliances by a friend's truck or business cooperation, which was associated with building social relations based on reciprocal gifts and favours (see Sneath 2006: 94).

Therefore, upon closer inspection we see that we have entered an area where the social and cultural fabric functions in a completely different, complex manner, and the interpersonal may be a source of positive relations, including the informal negotiation of cooperation and business ties, and the creation of a certain quasi-economic and quasi-political force. It can be observed in Bulgan, where people face challenges which involve informality; the do business on the border and rely on the established relations with customs officials, guards, contractors, and they arrange and rearrange relationships within their family. All these kinship and friendship relationships extend to Ulaanbaatar and to the estates inhabited by the Torghuts, particularly in Torguud Town. At some point these groups of brothers-businessmen start to act for the benefit of the society; they invent, organize and encourage the worship of their town and mountains, they build up "pride" and organize 
competitions. In the restaurants and clubs of Ulaanbaatar, and during meetings in Bulgan offices, they come up with lots of ideas concerning what can be done, and they raise the bar. The effects can be seen immediately; the celebrations become increasingly lavish, the network of friends expands along with the network of interests in Ulaanbaatar, and in Bulgan itself the celebrations have become more and more significant; in the local idiom it could be described as building and winding in prosperity.

The Buuren Khayrkhan celebration of 2014 involved almost all the inhabitants. What could also be noticed was the symbolic and visual relocation of the town centre. In 2013 the council, a new school, as well as the hotel and restaurant belonging to a brother from one of the families, were located right next to the previously founded park called 'Torgon Nutag'. Thus the centre moved to the vicinity around the 'Torgon Nutag Park', which is now a meeting point for the young who come here to sit on benches, socialize or play basketball. From a certain perspective it is difficult to tell to what extent the local authorities organize these events, and to what extent it is the people, traders and businessmen from Bulgan. Not only officials or businessmen from the club are involved in the organization of the event, but also the people of the Sum, who perform during the celebrations, sing, speak to the assembled, all dressed in festive costumes - the Torghut deel; these are often small shopkeepers, owners of pharmacies, teachers and nursery employees. This gives rise to a specific, exuberant, largely unpredictable mechanism of cooperation. It takes the shape of cooperation, an informal share of benefits and business ambitions, but at some point it becomes a form of selforganization. In this way the mechanisms of joint action emerge at the time of holidays and visits. They bring out 'the best' in the life of the Sum ${ }^{5}$ and all that is the most 'worthy', providing joint acts of fortune-prosperity and spontaneously forming local ideas of development.

February 2016

5 When the club visited a local dormitory, businessmen received 'the best' watermelons from Bulgan, from the plantation run by the father of a local organizer; Bulgan, September 2014. 


\section{References}

Arce, Alberto - Long, Norman. 2000. Anthropology, Development and Modernities. London.

Crewe, Emma - Harrison, Elizabeth. 2002. Whose Development? An Ethnography of Aid. New York.

Empson, Rebeca. 2012. The Danger of Excess. Accumulating and Dispersing Fortune in Mongolia. Social Analysis 56: 1-12.

Empson, Rebeca. 2014. An Economy of Temporary Possession. Malinowski Memorial Lecture 2014. [2015-12-14] Retrieved from: http://www. Ise.ac.uk/publicEvents/ events/2014/05/20140522t1800vOT.aspx

Ferguson, James. 1994. The AntiPolitics Machine. 'Development', Depolitization and Bureaucratic Power in Lesotho. Cambridge. Hobart, Mark. 1993. An Anthropological Critique of Development. The Growth of Ignorance. London: Routledge.

Humphrey, Caroline. 2002. The Unmaking of Soviet Life. Everyday Economies after Socialism. London: Cornell University Press.

Humphrey, Caroline. 2012. Favors and 'Normal Heroes'. The Case of Postsocialist Higher Education. HAU: Journal of Ethnographic Theory 2, 2: 22-41.

Humphrey, Caroline - Ujeed, Hürelbaatar. 2012. Fortune in the Wind. An Impersonal Subjectivity. Social Analysis 56: 152-167.

Mosse, David. 2005. Cultivating Development: An Ethnography of Aid Policy and Practice. London.

Mróz, Lech. 1977. Rytm torguckiego koczowania. Etnografia Polska 21: 137-153.

Pfaffenberger, Bryan. 1992. Technology and Social Change. Annual Review of Anthropology 21: 491-516.

Rostow, Walt. 1960. The Stages of Economic Growth: A Non-Communist Manifesto. Cambridge: Cambridge University Press.
Sneath, David. 2002. Mongolia in the 'Age of Market'. Pastoral Land-use and the Development Discourse. In: Humphrey, Caroline - Mandel, Ruth (eds.): Markets and Moralities. Ethnographies of Postsocialism. Oxford.

Sneath, David. 2003. Land-Use, the Environment and Development in Post-socialist Mongolia. Oxford Development Studies 31, 4: 441-459.

Sneath, David. 2006. Transacting and Enacting: Corruption, Obligation and the Use of Monies in Mongolia. Ethnos 71: 89-112.

Stolpe, Ines. 2013. Transcending Religion: Intersection between Spatial, Social and Mental Mobility in Contemporary Mongolia. In: Mobilizing Religion: Networks and Mobility. Report on the crossroads Asia Conference. Bonn: Institute of Oriental and Asian Studies.

Szynkiewicz, Sławoj. 1977. Torguci Mongolii. Uwagi na tle pierwszych badań etnograficznych wśród Torgutów ałtajskich. Etnografia Polska 21: 118-136.

Szynkiewicz, Sławoj. 1981. Rodzina pasterska w Mongolii. Wrocław.

Szynkiewicz, Sławoj. 1993. Mongolia's Nomads Built a New Society Again: Social Structures and Obligations in the Eve of Privatisation. Nomadic Peoples 33: 163-172.

Tangad, Oyungerel. 2013. Scheda po Czyngis Chanie. Demokracja po mongolsku. Warszawa: Wydawnictwo Trio.

Villarreal, Magdalena. 2007. Power and Self-Identity. The Beekeepers of Ayuquila. In: Melhuus, Marit - Stølen, Kristi Anne (eds.): Machos, Mistresses, Madonnas. Contesting the Power of Latin American Gender Imagery. New York.

Wheeler, Alan. 2004. Moralities of the Mongolian 'Market'. A Genealogy of Trade Relations and the Zah Zeel. Inner Asia 6: 215-238. 


\section{Rozvoj zdola nahoru. Studie samoorganizace a budování blahobytu u Torgutů v Bulgan Sum v Mongolsku}

K místním komunitám v nezápadních zemích přistupují mezinárodní instituce často jako k pasivním subjektům, které je třeba vzdělávat pomocí expertů a reorganizovat podle západních socioekonomických modelů (Hobart 1993). Takový prrístup vede $k$ tomu, že řada rozvojových agentur mnohdy přehlíží a nezohledňuje vlastní formy společenské činnosti místních komunit a jejich pojetí sebeorganizace. $V$ tomto článku se zaměřujeme na proces změny v současném Mongolsku, probíhající zdola nahoru, a na vlastní, osobité představy a praktiky Mongolů, pokud jde o iniciování a zajištění rozvoje. Odkazujeme na výzkum provedený ve správním obvodu (somonu) Bulgan, nacházejícím se na jižních svazích Altaje. Od roku 2012 jsme prováděli terénní výzkum u dnešních Torgutů. Především se zaměřujeme na posttransformační ekonomické aktivity v Bulganu, k nimž patří kolektivní správa statků (Empson 2014), a na nové druhy podnikání, spojeného s přeshraničním obchodem. Studie pojednává o neformálních sítích podnikatelů a jejich způsobu budování vzájemně spřízněných obchodních vztahů. V tomto kontextu analyzujeme činnost uskupení „Torgon Nutag Club“, založeného skupinou torgutských podnikatelů, kteří ve svém domovském městě iniciovali a pořádali řadu sociálních a kulturních akcí a různých oslav. Většina členů klubu žije v Ulánbátaru v takzvaném „Torgutském městě“, které lze dnes považovat za jedno z hlavních intelektuálních center torgutské činnosti. Důležitá je zejména skutečnost, že Torguti tímto způsobem vytvářejí nejen spontánní a originální společenské organizace, ale také osobitý styl duchovně prospěšné činnosti. Podporují tak složky společného osudu, bohatství prosperity, životní energie a síly. 